Summary

An unselected group of 130 patients with symptoms of an acute infection of the urinary tract have been studied from general practice. Only $77(59 \%)$ of these 130 patients had infected urine. Treatment with sulphafurazole was possible in 72 , and was effective in 57 (79\% of those treated). A high incidence of infection observed in young women was apparently related to sexual activity rather than child-bearing.

Of the patients with symptoms suggesting acute infections of the urine $41 \%$ had urine free of infection on culture. These patients were regarded as having the "urethral syndrome."

Adequate follow-up was possible in 115 (85\%) patients; infection persisted or recurred in the three months after treatment in 25 out of 69 patients with initial infection. Bacilluria developed in the same period in 13 out of 46 patients without initial infection. Similarities between the patients with and without definite infection in the initial urine suggest that the "urethral syndrome" represents infection confined to the urethra and adjoining glands. This syndrome is part of the spectrum of infections of the lower urinary tract.

We are grateful to Sister E. C. Budge, of the District Nursing Service of the Auckland Hospital Board, for seeing patients in this study, and to Mr. J. Holland, who, with technicians of the Central Laboratory of the Auckland Hospital, examined the urines. We would thank Miss T. Hewitt for secretarial work involved in the trial. Roche Products Ltd. generously gave a grant-in-aid and supplied sulphafurazole (Gantrisin). Dr. J. Z. Montgomerie was supported by a grant from the New Zealand Medical Research Council.
REFERENCES

Bennett-Jones, M. J. (1962). Lancet, 1, 299.

Brod, J. (1956). Ibid., 1, 973.

Davis, D. M. (1956). 7. Urol. (Baltimore), 76, 270.

Eberhart, C. (1958). Ibid., 79, 293.

Edwards, K. D. G., and Whyte, H. M. (1958). Aust. F. exp. Biol. med. Sci., 36, 383.

Effersøe, P., and Jensen, E. (1963). Lancet, 1, 1342.

Folsom, A. I. (1931). F. Amer. med. Ass., 97, 1345.

Freedman, L. R. (1960). In The Biology of Pyelonephritis edited by E. L. Quinn and E. H. Kass, p. 345. Churchill, London.

Fry, J., Dillane, J. B., Joiner, C. L., and Williams, J. D. (1962). Lancet, 1, 1318.

Gray, L. A., and Pingelton, W. B. (1956). f. Amer. med. Ass., 162, 1361.

Guze, L. B., and Beeson, P. B. (1956). New Engl. F. Med., 255, 474.

Hodson, C. J. (1959). Proc. roy. Soc. Med., 52, 669.

Jackson, G. G., Poirier, K. P., and Grieble, H. G. (1957). Ann. intern. Med., 47, 1165.

Kass, E. H. (1960). In The Biology of Pyelonephritis, edited by E. L. Quinn and E. H. Kass, p. 399. Churchill, London.

Kindall, L., and Nickels, T. T. (1949). F. Urol. (Baltimore), 61, 222.

Kleeman, C. R., Hewitt, W. L., and Guze, L. B. (1960). Medicine (Baltimore), 39, 3.

Kunin, C. M., Deutscher, R., and Paquin, A. (1964). Ibid., 43, 91.

Loudon, I. S. L., and Greenhalgh, G. P. (1962). Lancet, 2, 1246.

MacDonald, R. A., Levitin, H., Mallory, G. K., and Kass, E. H. (1957). New Engl. 7. Med., 256, 915.

Ormond, J. K. (1935). F. Urol. (Baltimore), 33, 483.

Relman, A. S. (1960). In The Biology of Pyelonephritis, edited by E. L. Quinn and E. H. Kass, p. 355. Churchill, London.

Weiss, S., and Parker, F., jun. (1939). Medicine (Baltimore), 18, 221.

Wharton, L. R., Gray, L. A., and Guild, H. G. (1937). 9. Amer. med. Ass., 109, 1597.

Winberg, J., and Barr, M. (1960). Acta paediat. (Uppsala), 49, 203.

Winsbury-White, H. P. (1960). Proc. roy. Soc. Med., 53, 1016.

Youngblood, V. H., Tomlin, E. M., and Davis, J. B. (1957). ₹. Urol. (Baltimore), 78, 150.

Zufall, R. (1963). F. Amer. med. Ass., 184, 894.

\title{
Source of Elevated Serum Enzyme Activities in Patients with Megaloblastic Erythropoiesis Secondary to Folic-acid Deficiency
}

\author{
B. A. ElliOTT,* M.D., M.C.PATH. ; A. F. FLEMING, $†$ M.B., B.CHIR.
}

Brit. med. F., 1965, 1, 626-628

Elevated serum lactate dehydrogenase and $\alpha$-hydroxybutyrate dehydrogenase activities in patients with anaemia of pregnancy have been reported by Fleming and Elliott (1964). These high activities were not related to the severity of the anaemia but to the degree of megaloblastic marrow changes, and they fell rapidly with folic-acid therapy before the packed cell volume (P.C.V.) values rose, and before the restoration of wholly normoblastic erythropoiesis. A similar sequence of events has been observed in the levels of serum lactate dehydrogenase (Amelung, 1960) and of serum $\alpha$-hydroxybutyrate dehydrogenase (Elliott and Wilkinson, 1963) in patients on treatment for pernicious anaemia.

These observations suggest the megaloblastic tissues as the source of the elevated serum enzyme levels. In patients with pernicious anaemia the megaloblasts have been reported to be rich in enzymes (Heller et al., 1959), and it has been postulated that these are released into the blood by the increased destruction within the marrow of the abnormal red-cell precursors (Heller et al., 1960a). A similar process might explain the high serum lactate dehydrogenase and $\alpha$-hydroxybutyrate dehydrogenase activities in patients with folic-acid deficiency.

\footnotetext{
* Senior Lecturer, Department of Chemical Pathology, University College

Hospital, Ibadan, Nigeria.
† Senior Registrar, Subdepartment of Haematology, University College Hospital, Ibadan, Nigeria.
}

Since these patients are commonly admitted to University College Hospital, Ibadan, it was decided to investigate the relation between their blood serum and bone-marrow lactate dehydrogenase and $\alpha$-hydroxybutyrate dehydrogenase activities.

\section{Materials and Methods}

Patients Studied.-Six patients with Burkitt's tumour were found to have normoblastic marrows when they were investigated prior to chemotherapy. Of 17 patients with anaemia (see Table) the marrows of three showed early transitional megaloblastic change, four showed transitional change, and 10 were frankly megaloblastic. Fourteen of these patients were pregnant, and three had been recently delivered.

Serum Folic-acid Activities.-Activities were measured by bioassay using Lactobacillus casei as the test organism (Herbert, 1961).

Serum Vitamin-B $B_{12}$ Activities.-These were assayed using L. leichmannii as the test organism (Rosenthal and Sarett, 1952).

Marrow Preparations.-Marrow specimens were collected from the iliac crest using ethylenediamine-tetra-acetic acid as an anticoagulant. Heparin and oxalate were not used, as they partially inhibit enzyme activity (Plummer and Wilkinson, 
1961 ; Elliott et al., 1962). Films were prepared and the rest of the specimens were centrifuged at 500 r.p.m. for 30 minutes at $4^{\circ} \mathrm{C}$. immediately after collection. After removal of the supernatant plasma an extract of the nucleated cell layer was prepared by homogenization in $5 \mathrm{ml} .0 .067 \mathrm{M}$ Sørensen phosphate buffer ( $p \mathrm{H}$ 7.4), using an ultrasonic disintegrator followed by freeze-thawing and further centrifugation.

Nitrogen Concentration of Marrow Tissue Extracts.-The micro-Kjeldahl method was employed as described by King and Wootton (1956).

Enzyme Determinations. - The lactate dehydrogenase and $\alpha$-hydroxybutyrate dehydrogenase activities of blood serum, marrow plasma, and cellular extracts were estimated by the spectrophotometric method of Wróblewski and LaDue (1955) at $25^{\circ} \mathrm{C}$., and the results were expressed in $\mu$ molar units per litre or per milligram of nitrogen in the case of the tissue extracts. The nitrogen concentration of the extracts was used as an index of the amount of protein, and therefore of the tissue, originally present. The expression of enzyme activities in terms of nitrogen provided a reference standard for the enzyme content of the tissues. In retrospect it is appreciated that the phosphorus concentration would have been a better reference standard.

\section{Results}

Serum-vitamin Concentrations.-In 14 of the 17 patients with marrow changes the total serum folic acid was below $4.6 \mathrm{~m} \mu \mathrm{g} . / \mathrm{ml}$., the lower normal limit in Nigerians. One patient had a value of $5.3 \mathrm{~m} \mu \mathrm{g} . / \mathrm{ml}$.; another to whom folic acid had been given had a higher than normal value; the estimation was not done in one other. Eight patients had normal serum-vitamin $B_{12}$ concentrations, one had received the vitamin, and the estimation was not performed in the remaining eight (see Table).

Serum Enzyme Activities.-The upper limits of normal for serum lactate dehydrogenase and serum $\alpha$-hydroxybutyrate dehydrogenase are 240 and 140 units/1. respectively. The activities were normal in the six patients with normoblastic marrows and in the three anaemic patients with early transitional marrow changes, apart from one of the latter who had a marginally elevated serum $\alpha$-hydroxybutyrate dehydrogenase

\begin{tabular}{|c|c|c|c|c|c|c|c|c|}
\hline \multirow{2}{*}{$\begin{array}{l}\text { Blood } \\
\text { P.C.V. } \\
\text { (\%) }\end{array}$} & \multirow{2}{*}{$\begin{array}{l}\text { Serum } \\
\text { Folic } \\
\text { Acid } \\
\text { (m } \mu \mathrm{g} .1 \\
\text { ml. })\end{array}$} & \multirow{2}{*}{$\begin{array}{c}\text { Serum } \\
\text { Vit. } \\
\text { B }_{12} \\
(\mu \mu \mathrm{g} . / \\
\text { ml. })\end{array}$} & \multicolumn{2}{|c|}{$\begin{array}{l}\text { Serum Enzymes } \\
(\mu \text { molar units } / 1 .)\end{array}$} & \multicolumn{2}{|c|}{$\begin{array}{c}\text { Marrow Plasma } \\
(\mu \text { molar units } / 1 .)\end{array}$} & \multicolumn{2}{|c|}{$\begin{array}{c}\text { Marrow Tissues } \\
(\mu \text { molar units } / \\
\left.\text { mg. } \mathrm{N}_{2}\right)\end{array}$} \\
\hline & & & L.D. & | H.B.D. & L.D. & H.B.D. & L.D. & H.B.D. \\
\hline \multicolumn{9}{|c|}{ Normoblastic } \\
\hline $\begin{array}{l}= \\
\bar{z}\end{array}$ & $\begin{array}{l}E \\
z \\
z\end{array}$ & $\begin{array}{l}= \\
\bar{z}\end{array}$ & $\begin{array}{l}190 \\
175 \\
165 \\
150 \\
110 \\
125\end{array}$ & $\begin{array}{r}125 \\
110 \\
110 \\
95 \\
85 \\
90\end{array}$ & $\begin{array}{r}650 \\
660 \\
970 \\
650 \\
680 \\
1,000\end{array}$ & $\begin{array}{l}650 \\
430 \\
725 \\
660 \\
430 \\
825\end{array}$ & $\begin{array}{l}0.40 \\
0.03 \\
0.30 \\
0.30 \\
0.46 \\
0.37\end{array}$ & $\begin{array}{l}0.30 \\
0.03 \\
0.13 \\
0.18 \\
0.33 \\
0.26\end{array}$ \\
\hline \multicolumn{9}{|c|}{ Early Transitional Megaloblastic } \\
\hline $\begin{array}{l}17 \\
32 \\
20\end{array}$ & $\begin{array}{l}2 \cdot 4 \\
2 \cdot 6 \\
3 \cdot 1\end{array}$ & $\overline{-}$ & $\begin{array}{l}145 \\
205 \\
170\end{array}$ & $\begin{array}{l}120 \\
165 \\
120\end{array}$ & $\begin{array}{r}950 \\
1,360 \\
1,775\end{array}$ & $\begin{array}{r}770 \\
1,250 \\
1,230\end{array}$ & $\begin{array}{l}1 \cdot 10 \\
0.74 \\
0.94\end{array}$ & $\begin{array}{l}0.70 \\
0.60 \\
0.62\end{array}$ \\
\hline \multicolumn{9}{|c|}{ Transitional Megaloblastic } \\
\hline $\begin{array}{l}22 \\
15 \\
14 \\
10\end{array}$ & $\left|\begin{array}{r}3 \cdot 4 \\
4 \cdot 5 \\
5 \cdot 3 \\
>28\end{array}\right|$ & $\left|\begin{array}{c}\bar{z} \\
>275 \\
2,000\end{array}\right|$ & $\begin{array}{r}170 \\
215 \\
625 \\
1,400\end{array}$ & $\begin{array}{r}160 \\
200 \\
550 \\
1,000\end{array}$ & $\begin{array}{l}1,450 \\
1,400 \\
1,800 \\
2,750\end{array}$ & $\begin{array}{l}1,100 \\
1,050 \\
1,500 \\
2,025\end{array}$ & $\begin{array}{l}0.90 \\
0.75 \\
0.64 \\
0.61\end{array}$ & $\begin{array}{l}0.60 \\
0.50 \\
0.50 \\
0.44\end{array}$ \\
\hline \multicolumn{9}{|c|}{ Megaloblastic } \\
\hline $\begin{array}{l}15 \\
18 \\
13 \\
11 \\
13 \\
13 \\
12 \\
10 \\
9 \\
11\end{array}$ & $\begin{array}{l}3.5 \\
2.4 \\
3.4 \\
2.2 \\
1.6 \\
1.8 \\
4.5 \\
1.4 \\
1.0 \\
-\end{array}$ & $\begin{array}{c}1,125 \\
625 \\
450 \\
-800 \\
375 \\
400 \\
450\end{array}$ & $\begin{array}{r}592 \\
675 \\
720 \\
875 \\
1,150 \\
1,150 \\
1,550 \\
1,850 \\
2,200 \\
3,800\end{array}$ & $\begin{array}{r}450 \\
560 \\
540 \\
810 \\
1,000 \\
1,025 \\
1,260 \\
1,675 \\
1,630 \\
2,800\end{array}$ & $\begin{array}{l}1,675 \\
1,850 \\
1,660 \\
1,700 \\
2,150 \\
2,580 \\
2,750 \\
6,000 \\
6,000 \\
6,500\end{array}$ & $\begin{array}{l}1,350 \\
1,300 \\
1,400 \\
1,400 \\
1,900 \\
2,500 \\
3,000 \\
4,400 \\
4,500 \\
4,950\end{array}$ & $\begin{array}{l}0.83 \\
0.33 \\
0.76 \\
0.53 \\
0.79 \\
1.25 \\
1.20 \\
1.23 \\
1.23 \\
1.25\end{array}$ & $\begin{array}{l}0.63 \\
0.30 \\
0.57 \\
0.44 \\
0.60 \\
1.00 \\
0.87 \\
1.00 \\
1.02 \\
1.01\end{array}$ \\
\hline
\end{tabular}

level. All the other patients had raised $\alpha$-hydroxybutyrate dehydrogenase levels, and all but two had raised lactate dehydrogenase levels (see Table).

Marrow Plasma Enzyme Activities.-The lactate dehydrogenase and $\alpha$-hydroxybutyrate dehydrogenase activities of the marrow plasma of the six patients with normoblastic marrows ranged from 650 to 1,000 and 430 to 825 units/l. respectively. The lowest values for each enzyme were therefore much greater than the upper normal limits for blood serum. 'With the exception of one patient with an early transitional megaloblastic marrow, all patients with marrow changes had marrow plasma lactate dehydrogenase above 1,350 units and $\alpha$-hydroxybutyrate dehydrogenase values above 1,000 units.

Fig. 1 shows a direct correlation between the raised blood serum $\alpha$-hydroxybutyrate dehydrogenase activities and those of the corresponding marrow plasma. In each case the marrow activities were greater than those of the blood. The findings for lactate dehydrogenase activities were similar.

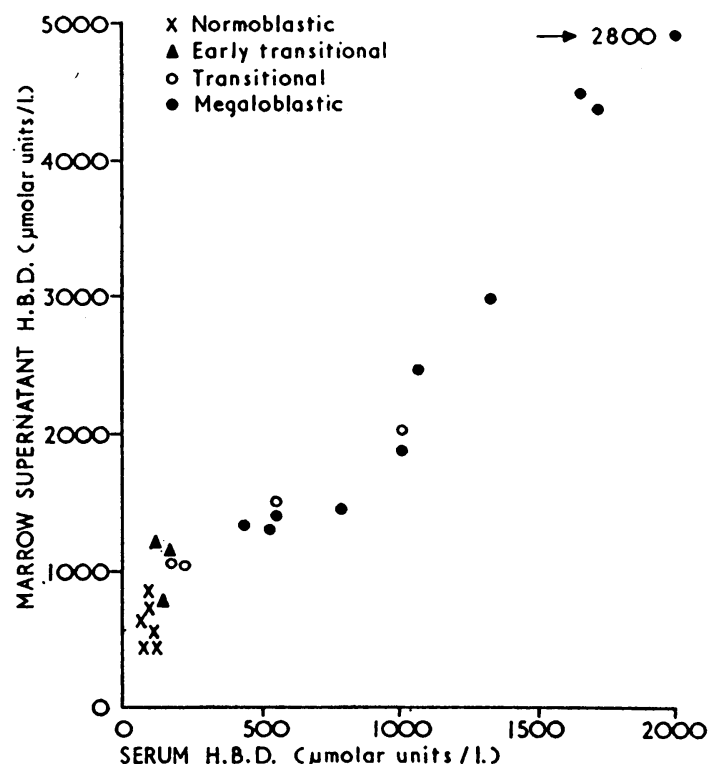

FiG. 1. $-\alpha$-Hydroxybutyrate dehydrogenase (H.B.D.) activities of blood serum related to those of marrow plasma in normoblastic and megaloblastic marrows.

Marrow Extract Enzyme Activities.-All but one of the patients with marrow changes had tissue extract $\alpha$-hydroxybutyrate dehydrogenase activities of more than $0.4 \mathrm{unit} / \mathrm{mg}$. nitrogen (Fig. 2). All the patients with normoblastic marrows had values below this figure. There was no direct correlation between marrow extract activities and those of marrow plasma, but the five patients with the highest extract values also exhibited the highest plasma values. The findings for lactate dehydrogenase activities were again similar.

\section{Discussion}

The marrow plasma of all patients in this series exhibited higher lactate dehydrogenase and $\alpha$-hydroxybutyrate dehydrogenase activities than their peripheral blood sera (Fig. 1). In the patients with abnormal marrows the elevated blood-serum enzyme levels reflected high marrow plasma levels. This observation suggests that the raised blood levels in these patients were derived from megaloblastic marrow tissue, and not from other tissues, such as hypoxic skeletal or cardiac muscle secondary to the anaemia itself. This view is supported by the finding that the blood enzyme levels are directly related to the degree of megaloblastic change in the marrow and not to the severity of the anaemia (Fleming and Elliott, 1964).

The high marrow plasma enzyme activities in the patients with megaloblastic marrow changes may result simply from the 
accelerated destruction of abnormal red-cell precursors within the marrow, secondary to inefficient erythropoiesis (Finch et al., 1956 ; Witts, 1961) and the release of cellular enzymes into the surrounding plasma. On the other hand, the enzyme concentrations of the megaloblastic marrow tissues were, with the exception of one with minimal change, greater than those of the normoblastic marrows (Fig. 2). It is unlikely that the increased lactate dehydrogenase concentration of the megaloblastic marrows can be fully explained by the increased proportion of immature red cells present in these marrows. Immature red cells of normoblastic marrows have a larger complement of glycolytic enzymes than mature cells, but the lactate dehydrogenase concentration is the same irrespective of the stage of maturity (Marks et al., 1958 ; Bernstein, 1959).

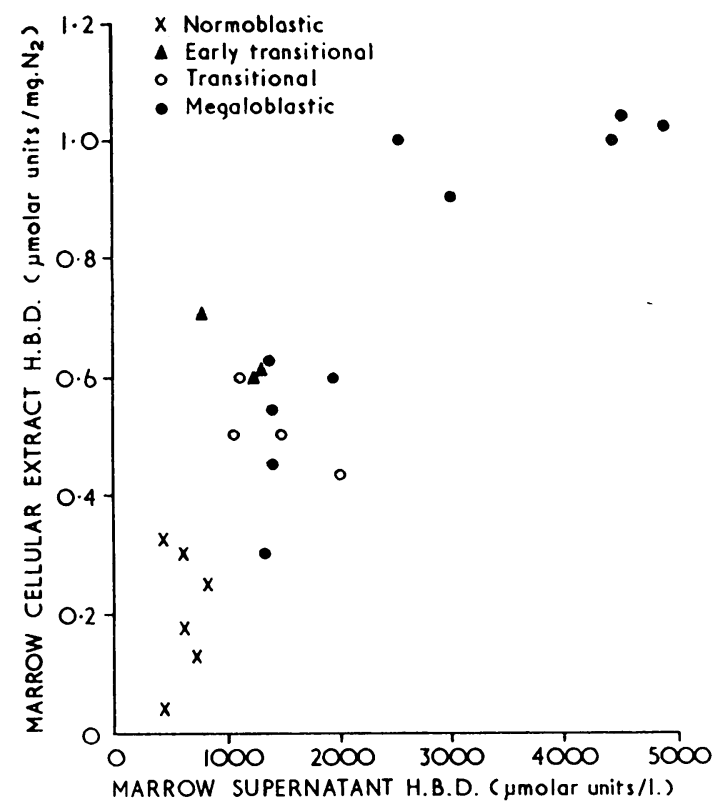

FIG. 2.- $\alpha$-Hydroxybutyrate dehydrogenase (H.B.D.) activities of marrow plasma related to marrow cellular activities in normoblastic and megaloblastic marrows.

The alternative explanation for the increased lactate dehydrogenase and $\alpha$-hydroxybutyrate dehydrogenase content of megaloblastic marrows is an increased enzyme content of the individual erythroid cells, as suggested by Heller et al. (1960b), and that this increased content reflects greater metabolic activity or failure of utilization or both. The available evidence indicates that during the development of megaloblastosis in patients with vitamin- $\mathrm{B}_{12}$ or folic-acid deficiency the abnormal red-cell precursors acquire a higher concentration of certain enzymes, including lactate dehydrogenase and $\alpha$-hydroxybutyrate dehydrogenase, than their normal counterparts. This increased enzyme content associated with an accelerating destruction rate of the cells causes the release of large amounts of enzyme protein into the marrow plasma. The rising lactate dehydrogenase and $\alpha$-hydroxybutyrate dehydrogenase activities in peripheral blood serum reflect the rising marrow plasma activities.

\section{Summary}

The raised serum lactate dehydrogenase and $\alpha$-hydroxybutyrate dehydrogenase activities in patients with megaloblastic erythropoiesis secondary to folic-acid deficiency are derived from high concentrations in the marrow plasma. According to available evidence these high concentrations in turn result from the increased destruction within the marrow of abnormal red-cell precursors with a high enzyme content.

We are grateful to Professor J. B. Lawson, Professor J. C. Edozien, and Dr. N. C. Allan for helpful advice and criticism. We also thank our colleagues of the Department of Obstetrics and Gynaecology for permission to study patients under their care, and Mr. A. K. Afolabi, a medical student, for technical assistance.

\section{REFERENCES}

Amelung, D. (1960). Dtsch. med. Wschr., 85, 1629.

Bernstein, R. E. (1959). F. clin. Invest., 38, 1572.

Elliott, B. A., Jepson, E. M., and Wilkinson, J. H. (1962). Clin. Sci.,

23, 305 .

Fleming, A. F., and Elliott, B. A. (1964). Brit. med. 7., 2, 1108.

Finch, C. A., Coleman, D. H., Motulsky, A. G., Donohune, D. M., and Reiff, R. H. (1956). Blood, 11, 807.

Heller, P., West, M., and Zimmerman, H. J. (1959). Clin. Res., 7, 207. Weinstein, H.' G., West, M., and Zimmerman, H. J. (1960a). F. Lab. clin. Med., 55, 425.

- (1960b). Ann. intern. Med., 53, 898.

Herbert, V. (1961). 7. clin. Invest., 40, 81.

King, E. J., and Wootton, I. D. P. (1956). Micro-analysis in Medical Biochemistry, 3rd ed. Churchill, London.

Marks, P. A., Johnson, A. B., and Hirshberg, E. (1958). Proc. nat. Acad. Sci. (Wash.), 44, 529.

Plummer, D. T., and Wilkinson, J. H. (1961). Biochem. 7., 81, 38P.

Rosenthal, H. L., and Sarett, H. P. (1952). F. biol. Chem., 199, 433.

Witts, L. J. (1961). Brit. med. F., 2, 325.

Wróblewski, F., and LaDue, J. S. (1955). Proc. Soc. exp. Biol. (N.Y.), 90, 210 .

\title{
Natulan in Management of Late Hodgkin's Disease, Other Lymphoreticular Neoplasms, and Malignant Melanoma
}

\author{
I. D. H. TODD,* M.B., M.R.C.P., F.F.R., D.M.R.T.
}

Brit. med. F., 1965, 1, 628-631

Bollag and Grunberg (1963) described the tumour-inhibitory effects of methyl-hydrazine derivatives. As a result one of these agents, Natulan (1-methyl-2-p-(isopropylcarbamoyl) benzyl-hydrazine chlorhydrate), has been undergoing clinical trials. Mathé, Berumen, Schweisguth, Brule, Schneider, Cattan, Amiel, and Schwarzenberg (1963) described their experience in treating 44 patients, and concluded that it was "of considerable value in the treatment of Hodgkin's disease." Sicher and Backhouse (1963) confirmed the benefits of this

\footnotetext{
- Consultant Radiotherapist, Christie Hospital and Holt Radium Institute,
Manchester.
}

drug, but did not think it should yet replace more firmly established cytotoxic agents.

\section{Clinical Material and Methods of Administration}

There were 40 patients in this series, of whom 33 had lymphoreticular disease: Hodgkin's disease, 24 cases ; lymphosarcoma, 5 cases ; mycosis fungoides, 2 cases; Brill-Symmers disease, 1 case ; reticulum-cell sarcoma, 1 case ; melanomatosis, 6 cases ; and carcinomatosis (primary unknown), 1 case. 